\title{
Roe protein hydrolysate of Alburnus tarichi induces apoptosis in breast cancer MCF-7 and MDA-MB-231 cells through a caspase-dependent pathway
}

\author{
Mehmet Berköz ${ }^{1}$, Ferbal Özkan-Yılmaz², Arzu Özlüer-Hunt ${ }^{3}$, Mirosław Krośniak $^{4}$, \\ Ömer Türkmen ${ }^{5}$ and Oruç Yunusoğlu ${ }^{6}$ \\ ${ }^{1}$ Department of Biochemistry, Faculty of Pharmacy, Van Yuzuncu Yil University, Van, Turkey \\ ${ }^{2}$ Department of Basic Sciences, Faculty of Fisheries, Mersin University, Mersin, Turkey \\ ${ }^{3}$ Department of Aquaculture, Faculty of Fisheries, Mersin University, Mersin, Turkey \\ ${ }^{4}$ Department of Food Chemistry and Nutrition, Medical College, Jagiellonian University, Kraków, Poland \\ ${ }^{5}$ Department of Pharmaceutical Technology, Faculty of Pharmacy, Van Yuzuncu Yil University, Van, Turkey \\ ${ }^{6}$ Department of Medical Pharmacology, Faculty of Medicine, Van Yuzuncu Yil University, Van, Turkey
}

\begin{abstract}
The protein hydrolysates of fishes have been reported to be a potential source of many health benefits components for pharmaceutical or nutritional applications. The aim of this study is to examine the possible antiproliferative function of roe protein hydrolysates of Alburnus tarichi using enzymatic hydrolysis against breast cancer cells and explore its detailed mechanisms. In addition, we evaluated the effects of protein hydrolysate on the proliferation and apoptosis of two human breast cancer cell lines (MCF-7 and MDA-MB-231). The cultured cells were treated with protein hydrolysate at concentrations of $0-5 \mu \mathrm{g} / \mathrm{ml}$ for $24 \mathrm{~h}$ and $48 \mathrm{~h}$. Inhibition of cell proliferation, percentage of apoptotic cells, cell cycle distribution, morphological changes, DNA fragmentation, intracellular reactive oxygen species (ROS) production, and apoptotic protein levels were also examined. Decreases in proliferation of MCF-7 and MDA-MB-231 cells were observed after treatment with the protein hydrolysate in a dose-dependent manner. Distinct morphological changes, a typical pattern of fragmented DNA, and increased intracellular ROS production and apoptotic protein levels were observed in both cell lines after hydrolysate treatment $(p<0.05)$. The results suggested that the protein hydrolysate inhibits the proliferation of human breast cancer cell lines by introducing apoptosis through a caspase-dependent pathway in a dose-dependent manner.
\end{abstract}

Key words: Alburnus tarichi - Roe protein hydrolysate - Breast cancer - Apoptosis

\section{Introduction}

Breast cancer is an important public health problem worldwide, which is the second most common cancer diagnosed and is also a prime reason of death in women globally. It has become a fatal disease, and risk factors associated with breast cancer seem to be expanding day by day (Cedolini et al. 2014). Chemotherapy, radiation therapy, and im-

Correspondence to: Mehmet Berköz, Department of Biochemistry, Faculty of Pharmacy, Van Yuzuncu Yil University, Zeve Campus, 65080 Van, Turkey

E-mail:mehmet_berkoz@yahoo.com munotherapy all rely heavily on apoptosis to kill breast cancer cells (Espinosa et al. 2003). The development of chemotherapeutic agents which are unaffected by common mechanisms of chemo resistance and lack of the toxicity of predictable chemotherapeutic agents would be a foremost advance in cancer treatment (Cassidy and Misset 2002). Hence, the research and development of more effectual and less toxic drugs by the pharmaceutical industry has become indispensible, stimulating a growing interest in the identification and characterization of natural antitumor substances. The eradication of cancer in the early stages is a fundamental part of chemoprevention and measuring the cytotoxic effects of a given compound in contradiction of 
cancer cells offers useful insight into its chemoprotective potential (Lind et al. 2001).

Fishes are a huge and diverse group of animals of which more than 100 species of fishes are used as traditional medicines for tumors. Though, only a few species were analyzed by chemically and has explored. Moreover, most of the natural products obtained from fishes are assessed and developed as functional food and these varieties of products are dominated by low molecular weight compounds. The fish tissue comprises a potential source of anticancer molecules to be explored. Fish proteins exemplify an essentially untapped resource for the discovery and development of possible antitumor drugs. Isolation of effective anticancer compounds from fish tissue is a solid argument to consider that fishes might constitute a source of anticancer or chemopreventive molecules (Wang et al. 2012). Amino acids, peptides and proteins have been stated to show antitumour or antiproliferative activities. The protein hydrolysates of fishes have been reported to be a potential source of many health benefits components for pharmaceutical or nutritional applications (Hung et al. 2014). However, the peptide derived from fish protein hydrolysates has been rarely studied for antiproliferative activity.

Alburnus tarichi (pearl mullet) is an anadromic endemic carp species that migrates to streams (between mid-April and mid-July) living in the high $\mathrm{pH}$ waters of Lake Van and pouring into the lake for breeding. According to TurkStat data, this fish is hunted around 10,000 tons per year on average. Therefore, it is an economically important species. A. tarichi can leave approximately 6.000-16.000 eggs depending on the internal and external factors such as age, size and nutrition level of the fish. The eggs are very small and about $1 \mathrm{~mm}$ in diameter. Due to its fast growth and suitable price, $A$. tarich $i$ currently is regarded a high economic value fish species in Turkey (Oğuz 2018).

To the best of our knowledge, there is no report regarding anticancer activity of fish protein hydrolysate of A. tarichi available. Therefore, the main objective of this study is to examine the possible antiproliferative function of roe protein hydrolysates of $A$. tarichi using enzymatic hydrolysis against breast cancer cells and explore its detailed mechanisms.

\section{Materials and Methods}

\section{Preparation of defatted fish roe}

A. tarichi was obtained freshly from several fishermans in Van, Turkey, in March 2019. In order to carry out the study, necessary permissions were obtained from Van Animal Experiments Local Ethics Committee of Van Yuzuncu Yil University (Decision number: 2019/03, Date:
28.03.2019). The fishes were placed in ice and transported to the laboratory within $1 \mathrm{~h}$. All the fishes were sacrificed anf the whole roes were cleaned using cool water $\left(+4^{\circ} \mathrm{C}\right)$ and homogenized in a cool room. The homogenized roes were then freeze-dried. Afterward, lipids of the dried egg powders were extracted as described previously (Bligh and Dyer 1959). In brief, each $100 \mathrm{~g}$ freeze-dried homogenized roes were added to $300 \mathrm{ml}$ hexane for $2 \mathrm{~h}$ fat extraction. This procedure was repeated three times. Moreover, the solvents were evaporated by vacuum concentration. The defatted roe protein samples were then freeze-dried. The defatted roe powders were kept in sealed polyethylene bag and then placed at $-40^{\circ} \mathrm{C}$ until use.

\section{Preparation of roe protein hydrolysate of $A$. tarichi}

Roe protein hydrolysate was prepared from defatted A. tarichi roe powder using Protease N (Amano Pharmaceutical Co., Nagoya, Japan). 5 g defatted sample was suspended in a $250 \mathrm{ml}$ of $\mathrm{pH} 8.0$ phosphate buffer. The hydrolysis reaction was initiated by the ratio of Protease N/egg sample at 1:100 (w/w solid matter). The reaction was conducted at $\mathrm{pH} 8.0$ and $50^{\circ} \mathrm{C}$ for $9 \mathrm{~h}$. The enzymatic hydrolysis was ended by heating the mixtures at $90^{\circ} \mathrm{C}$ for $10 \mathrm{~min}$ to inactivate the protease activity. The solution containing hydrolysate was centrifuged at $5000 \times g$ for $10 \mathrm{~min}$ at $4^{\circ} \mathrm{C}$. Then, the supernatants were desalted and lyophilized to dried roe protein hydrolysate for storage at $-40^{\circ} \mathrm{C}$ (Bligh and Dyer 1959).

\section{Cell cultures}

The human breast cancer cell lines (MCF-7 and MDAMB-231) were selected as breast cancer cell models in this research. MCF-7 and MDA-MB-231 cell lines were obtained from American Type Culture Collection (ATCC). MCF-7 cells are useful for in vitro breast cancer studies due to their capacity to process estrogen via estrogen receptors in the cell cytoplasm, which makes the MCF-7 cell line an estrogen receptor (ER) positive control cell line. MDA-MB-231 breast cancer cells have an epithelial-like morphology, which appear phenotypically as spindle shaped cells. The difference between the two cell lines is that MCF-7 is an ER-positive breast cancer line derived from an in situ carcinoma, meaning that the cancerous cells had not yet invaded surrounding tissues; however, the MDA-MB-231 is an ER-negative breast cancer line derived from a metastatic carcinoma. Selection of both cell lines helps in better illustrating and understanding the mechanism of roe protein hydrolysate induced growth inhibition on human breast cancer. Both cell lines were grown adherently as a monolayer in $75 \mathrm{ml}$ plastic flasks in DMEM medium supplemented with $10 \%$ FBS (heat inactivated 30 minutes, $56^{\circ} \mathrm{C}$ before use), $100 \mathrm{U} / \mathrm{ml}$ penicillin, 
and $100 \mu \mathrm{g} / \mathrm{ml}$ streptomycin in incubator under standard cultured condition $\left(37^{\circ} \mathrm{C}\right.$ and $\left.5 \% \mathrm{CO}_{2}\right)$. For enumeration, $30 \mu \mathrm{l}$ of trypan blue $(0.2 \%)$ stained the same volume $(30 \mu \mathrm{l})$ of cell concentration, and neobar lam was used for counting and viability (more than 95\% for adhering cell lines before testing) of the cells.

\section{Antiproliferation assay}

Cell proliferation was investigated using MTT assay (Motomura et al. 2008). Cells were detached from the $25 \mathrm{~cm}^{3}$ tissue culture flask when it achieved $80 \%$ confluency. The detached cells were pelleted by centrifugation $(200 \times g ; 5 \mathrm{~min})$. Cells $\left(3 \times 10^{4}\right.$ cells $\left./ \mathrm{ml}\right)$ were seeded onto a 96-well microtiter plate. The cells were incubated at $37^{\circ} \mathrm{C}$ carbon dioxide $\left(\mathrm{CO}_{2}\right)$ incubator for $24 \mathrm{~h}$ to give adherent cells. The test hydrolysates $(0.25,0.5,0.75,1,2.5$, and $5 \mu \mathrm{g} /$ $\mathrm{ml}$ ) were added onto the 96 -well microtiter plate containing adherent cells. The untreated cells were incubated in $10 \%$ media containing $0.5 \%$ dimethyl sulfoxide (DMSO) (without addition of any test hydrolysates) as control group. The plates were incubated for $24 \mathrm{~h}$, and $48 \mathrm{~h}$ at $37^{\circ} \mathrm{C}$ in a $5 \% \mathrm{CO}_{2}$ incubator. After these periods, the media were removed and $100 \mu \mathrm{l}$ of fresh medium and $20 \mu \mathrm{l}$ of MTT (Sigma, filter sterile, $5 \mathrm{mg} / \mathrm{ml}$ ) were added to each well and further incubated for $4 \mathrm{~h}\left(37^{\circ} \mathrm{C}\right)$ after which the media were substituted with $150 \mu \mathrm{L}$ DMSO. The 96-well microtiter plates were then agitated at room temperature onto an incubator shaker to dissolve the formazan crystals. The absorbance of the content of the plates was measured at $540 \mathrm{~nm}$ using a microplate reader. The percentage of inhibition of each test sample was calculated according to the following formula: Percentage of inhibition $(\%)=$ $\left(\mathrm{A}_{\text {control }}-\mathrm{A}_{\text {sample }}\right) / \mathrm{A}_{\text {control }} \times 100 \%$.

The average of three replicates was then obtained. The half maximal inhibitory concentration $\left(\mathrm{IC}_{50}\right)$ of hydrolysate for both period was calculated using GraphPad Prism version 5.02 for Windows (GraphPad Software, San Diego, California, USA). Concentrations around and above the $\mathrm{IC}_{50}$ value would be used in the further studies.

\section{Morphological changes}

MCF-7 and MDA-MB-231 cells were trypsinized and $5 \mathrm{ml}$ of growth medium were added, then the cell suspension was mixed well. Then $2 \mathrm{ml}$ of cell suspension was added to the sterilized test tubes containing cover slip. The test tubes were placed in a slanting position and kept in $\mathrm{CO}_{2}$ incubator for 2 days. The monolayer of cells formed in the cover slip was observed under Inverted microscope (Euromex, ED Arnhem, Netherlands) and were photographed using a digital camera (Nikon, Tokyo, Japan) (Allen et al. 1997; Zhu and Wang 1997; Akter et al. 2012).

\section{DNA fragmentation}

MCF-7 and MDA-MB-231 cells $\left(2 \times 10^{5}\right.$ cell $\left./ \mathrm{ml}\right)$ were treated with $1,2.5$, and $5 \mu \mathrm{g} / \mathrm{ml}$ doses of roe protein hydrolysate incubated for $48 \mathrm{~h}$. After the incubation period, DNA fragmentation was analyzed as described by Mendis et al. (2015). Gel electrophoresis was carried out with extracted DNA and visualized under ultraviolet (UV) light to assess the effect on DNA fragmentation using a Mini BisPro gel imaging system (DNR Bioimaging Systems, Jerusalem, Israel) following electrophoresis on a $2.0 \%$ agarose gel stained with ethidium bromide.

\section{Cell cycle distribution}

We performed flow cytometric analysis to assess whether roe protein hydrolysate affected cell cycle progression in MCF-7 and MDA-MB-231 cells. Being treated with different concentrations of roe protein hydrolysate $(1,2.5$, and $5 \mu \mathrm{g} / \mathrm{ml})$ for $48 \mathrm{~h}$, the cells were collected and fixed with $70 \%$ ice-cold ethanol. Thereafter we stored the cells at $-20^{\circ} \mathrm{C}$. Then the cells were washed and resuspended in cold PBS. RNA was digested with RNase A $(100 \mu \mathrm{g} / \mathrm{ml})$ and DNA was stained with propidium iodide (PI) $(50 \mu \mathrm{g} / \mathrm{ml})$. After incubation for $30 \mathrm{~min}$ in the dark at $37^{\circ} \mathrm{C}$, flow cytometry was performed to analyze cell cycle distribution (FACSCalibur, Becton Dickinson, USA) (Zhen et al. 2014).

\section{Apoptosis by annexin V/PI}

We conducted the annexin V-FITC and PI staining to evaluate the effects of roe protein hydrolysate $(1,2.5$, and $5 \mu \mathrm{g} / \mathrm{ml}$ ) on apoptosis in MCF-7 and MDA-MB-231 cells. Firstly, MCF-7 and MDA-MB-231 cells were plated into 6-well plates (Corning, USA) and then incubated with roe protein hydrolysate in different concentrations for $48 \mathrm{~h}$. The cells were collected, centrifuged, and then incubated with Annexin V- FITC/PI for 15 min at room temperature in the dark and was finally analyzed flow-cytometrically (Pilane et al. 2015).

\section{Intracellular ROS}

The intracellular reactive oxygen species (ROS) was estimated by fluorescent probe, 2',7'-dichlorohydrofluorescein diacetate $\left(\mathrm{H}_{2}\right.$-DCF-DA). This dye is deacetylated by intracellular esterase and converted to nonfluorescent 2',7'-dichlorohydrofluorescein $\left(\mathrm{H}_{2}-\mathrm{DCF}\right)$, which is rapidly oxidized to the highly fluorescent compound 2',7'-dichlorohydrofluorescein (DCF) in the presence of ROS. The MCF-7 and MDA-MB-231 cells were dispensed into 24-well plates for $1 \mathrm{~h}$. Then, the cells were incubated only with the DMEM medium used as control or treated with roe protein hydrolysate 
$(1,2.5$, and $5 \mu \mathrm{g} / \mathrm{ml})$ at $37^{\circ} \mathrm{C}$ for $22 \mathrm{~h}$. After $22 \mathrm{~h}$ of exposure, the samples were removed and centrifuged at $200 \times g$ for 5 min, washed with $\mathrm{PBS}$ at $37^{\circ} \mathrm{C}$, and labeled with $\mathrm{H}_{2}-\mathrm{DCFH}-$ DA for $30 \mathrm{~min}$ in the dark conditions, at $37^{\circ} \mathrm{C}$. Then, cells were washed with phosphate buffered saline (PBS) and ROS formation was quantified by flow cytometer (FACSCalibur, Becton Dickinson, USA) at $488 \mathrm{~nm}$ excitation and 532 emission considering a minimum of 10,000 total events for each sample in FlowJo programm as described by Wagner et al. (2010). Data are presented as fluorescence intensity (a.u.).

\section{Western blot analysis}

MCF-7 and MDA-MB-231 cells were treated with various concentrations of roe protein hydrolysate $(1,2.5$, and $5 \mu \mathrm{g} / \mathrm{ml}$ ) for $48 \mathrm{~h}$; then MCF-7 and MDA-MB-231 cells were lysed in lysis buffer (Radioimmunoprecipitation assay buffer (RIPA), $1 \mathrm{mM}$ phenylmethylsulfonyl fluoride (PMSF)) and phosphatase inhibitors (Roche, Germany) to extract the total protein. Proteins were separated by sodium dodecyl sulfate-polyacrylamide gel electrophoresis (SDS-PAGE) $(8 \%, 12 \%$ gels) under reducing conditions. The proteins were then electrophoretically transferred to nitrocellulose membranes. The membranes were blocked with 5\% skimmed

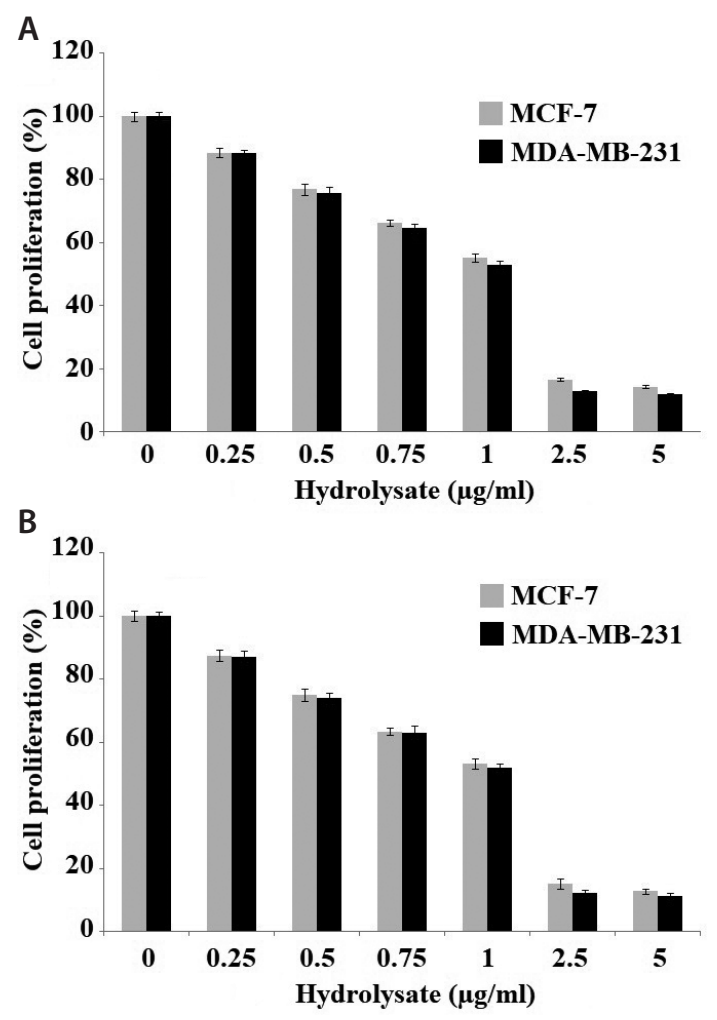

Figure 1. Dose-dependent anticancer effects of roe protein hydrolysate of A. tarichi on cell proliferation of MCF-7 and MDA-MB-231 cell lines for $24 \mathrm{~h}(\mathrm{~A})$ and for $48 \mathrm{~h}(\mathrm{~B})$ incubations. milk and incubated with anti-Caspase-3, anti-Caspase-7, anti-Caspase-8, anti-Caspase-9, anti-TNF- $\alpha$, anti-Bcl-2, anti-Bax, anti-COX-2, anti-p53, anti-Fas, anti-ErbB2, and anti- $\beta$-actin antibodies, respectively (1:1000; Cell Signaling Technology) overnight at $4^{\circ} \mathrm{C}$. After that, the membranes were incubated with secondary antibodies conjugated with horseradish peroxidase (HRP) for $1 \mathrm{~h}$ and then, treated with an enhanced chemiluminescence (ECL) substrate kit (Thermo Fisher Scientific Inc., Massachusetts, USA). Protein bands were quantified by ImageJ software with $\beta$-actin as internal loading controls and for normalizing purpose.

\section{Statistical analysis}

All experiments were performed in triplicate and results were presented as mean \pm standard deviation. Statistical analysis was performed by one-way analysis of variance (ANOVA) plus Tukey post-hoc analysis. Statistical analyses were performed using the (Statistical Package for the Social Sciences) SPSS software version 15.0 (SPSS Inc., Illinois, USA). A value $p<0.05$ was considered statistically significant.

\section{Results}

To determine the growth inhibitions of the protein hydrolysate on human breast cancer cell lines, the MTT assay was used to evaluate the antiproliferative activities after protein hydrolysate $(0.25-5 \mu \mathrm{g} / \mathrm{ml})$ treatment for $24 \mathrm{~h}$ and $48 \mathrm{~h}$. Figure $1 \mathrm{~A}$ and $\mathrm{B}$ shows that the protein hydrolysate inhibited the growth of both cell lines in a dose-dependent manner compared to control. The maximum growth inhibitions were achieved after 48 -h treatment with protein hydrolysate at the concentration of $5 \mu \mathrm{g} / \mathrm{ml}$ on MCF-7 (87.6\%) (Fig. 1A) and MDA-MB-231 (89.1\%; Fig. 1B). On the other hand, the growth inhibitions were achieved as $86.5 \%$ and $88.2 \%$, at the end of the 24-h incubation with protein hydrolysate at the concentration of $5 \mu \mathrm{g} / \mathrm{ml}$ on MCF-7 and MDA-MB-231cell lines, respectively (Fig. 1A and B). Significant decreases in survival of protein hydrolysate treated MCF-7 and MDA-MB-231 cells were observed compared to Control group $(p<0.05)$. The antiproliferative activities of protein hydrolysate on both breast cancer cell lines were increased along with the increasing dosages of protein hydrolysate. There were no significant differences in growth inhibitions of protein hydrolysate between the dosages of $5 \mu \mathrm{g} / \mathrm{ml}$ and $2.5 \mu \mathrm{g} / \mathrm{ml}$ on MCF-7 and MDA-MB-231 cells $(p>0.05)$. These results suggest that the growth inhibition activity of protein hydrolysate was saturated at a concentration of $2.5 \mu \mathrm{g} / \mathrm{ml}$ on MCF-7 and MDA-MB-231 cells. The protein hydrolysate had shown relatively higher antiproliferative activities on MDA-MB-231 cells at each concentration than on MCF-7 cells, but these differences were not statistically 

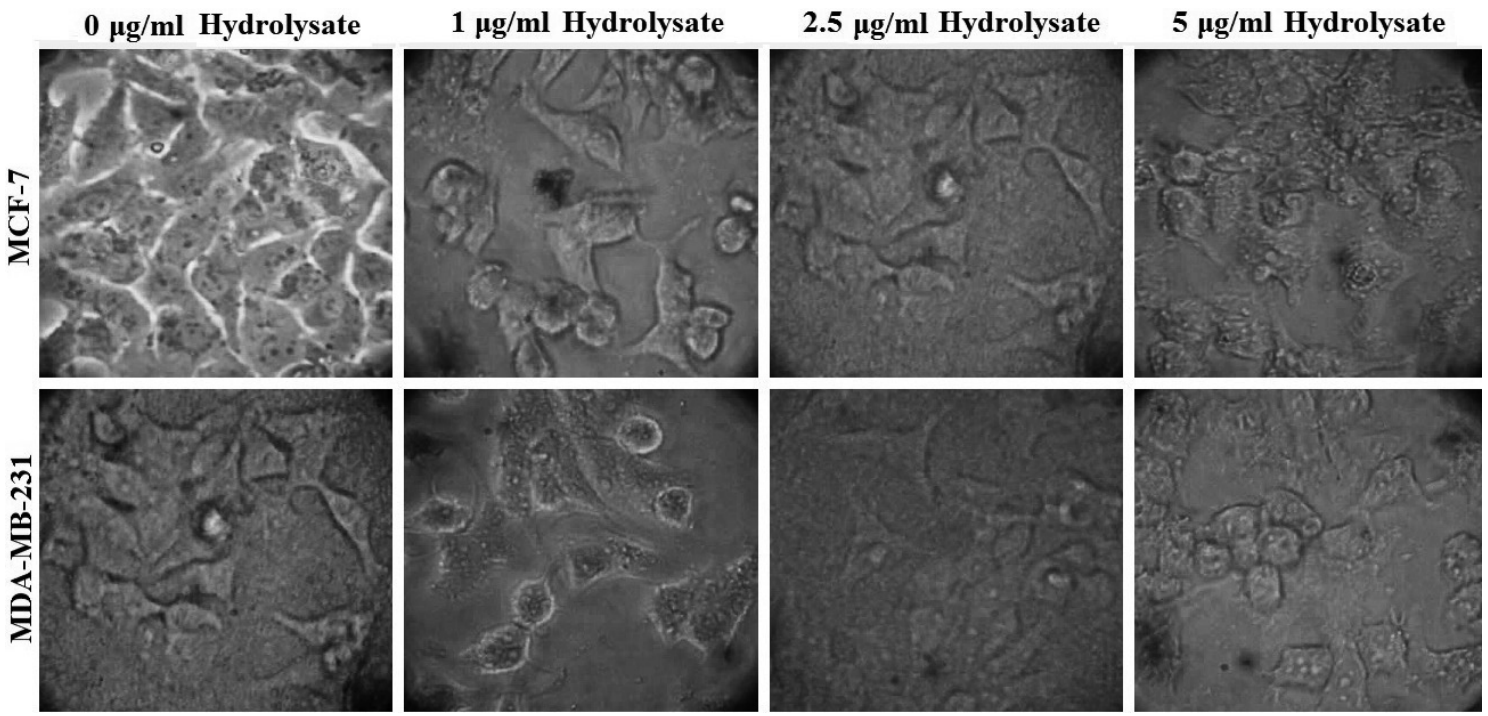

Figure 2. Effect of treatment with different concentration of roe protein hydrolysate on the morphology of MCF-7 and MDA-MB-231 cells. Cells were visualized using an inverted microscope (Euromex, ED Arnhem, Netherlands). Magnification, 100×.

significant $(p>0.05)$ (Fig. $1 \mathrm{~A}$ and $\mathrm{B}) . \mathrm{IC}_{50}$ values of roe protein hydrolysate on MCF-7 and MDA-MB-231 cells for $48 \mathrm{~h}$ incubation were found as $1.89 \mu \mathrm{g} / \mathrm{ml}$ and $1.81 \mu \mathrm{g} / \mathrm{ml}$, respectively. Concentrations around and above the $\mathrm{IC}_{50}$ value of the protein hydrolyzate $(1,2.5$, and $5 \mu \mathrm{g} / \mathrm{ml})$ were used in the following studies.

The morphological changes of the cells were visualized by inverted microscope. The control MCF-7 and MDA-MB-231 cells which were not treated with samples did not show any morphological changes. But the treated cell lines exhibited irregular confluent aggregates with rounded and polygonal cell morphology, this phenomenon was observed more frequently with increased concentrations of the roe protein hydrolysate (Fig. 2).

DNA fragmentation is a classic indicator of apoptosis. In the present study. MCF-7 and MDA-MB-231 cells treated with roe protein hydrolysate showed a DNA fragmentation in a time- and dose-dependent manner with both high molecular weight DNA and smaller DNA fragments extending from $2 \mathrm{kbp}$ to $100 \mathrm{bp}$. The control treated with $0.1 \%$ DMSO showed clear bands of intact DNA (Fig. 3).

To examine whether roe protein hydrolysate-induced growth inhibition was associated with cell cycle regulation, the cell cycle distribution was analyzed by flow cytometry (Fig. 4). After MCF-7 and MDA-MB-231 cells were incubated with the hydrolysate for $48 \mathrm{~h}$, cells were harvested and further prepared for cell cycle analysis. Figure 4A (MCF-7 cells) and Figure 4B (MDA-MB-231 cells) showed that cells accumulated in the $S$ phase of the cell cycle after the hydrolysate treatment, whereas the percentage of cells in $G_{0} / G_{1}$ phase reduced significantly. Especially, the percentage of cells in S phase increased by $29.4 \%$ and $30.3 \%$ for MCF-7 and MDA-MB-231 cells, respectively, when the hydrolysate concentration was $5 \mu \mathrm{g} / \mathrm{ml}$, compared to that of the untreated control $(p<0.05)$ (Fig. 4A and B).

Induction of apoptosis by roe protein hydrolysate was quantitatively determined by flow-cytometric analysis. For MCF-7 cells, early apoptotic cells increased from $11.1 \%$ at $2.5 \mu \mathrm{g} / \mathrm{ml}$ to $14.3 \%$ at $5 \mu \mathrm{g} / \mathrm{ml}$ of roe protein hydrolysate compared to $4.9 \%$ in the control at $48 \mathrm{~h}$ postincubation (Fig. 5A) $(p<0.05)$. For MDA-MB-231 cells, early apoptotic
A

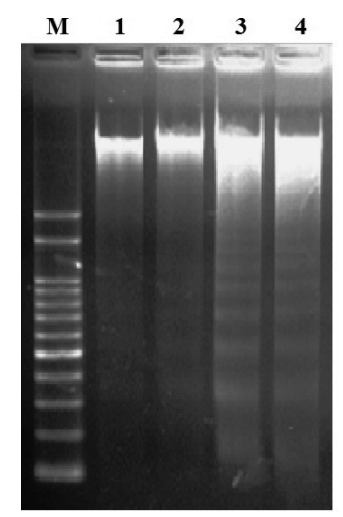

B

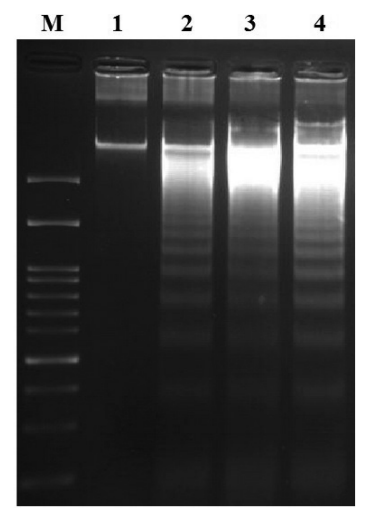

Figure 3. Induction of DNA fragmentation in MCF-7 cells (A) and MDA-MB-231 cells (B) by different concentration of roe protein hydrolysate. $\mathrm{M}$, marker; Line $1,0 \mu \mathrm{g} / \mathrm{ml}$ hydrolysate; Line 2, $1 \mu \mathrm{g} / \mathrm{ml}$ hydrolysate; Line 3, $2.5 \mu \mathrm{g} / \mathrm{ml}$ hydrolysate; Line $4,5 \mu \mathrm{g} / \mathrm{ml}$ hydrolysate. 
A

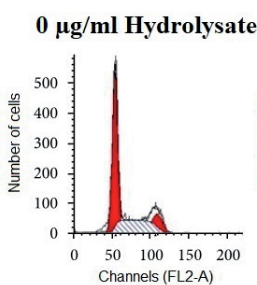

$2.5 \mu \mathrm{g} / \mathrm{ml}$ Hydrolysat
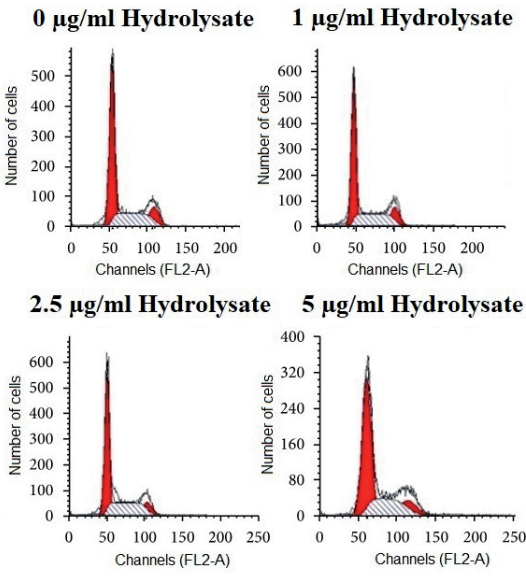

$5 \mu \mathrm{g} / \mathrm{ml}$ Hydrolysate

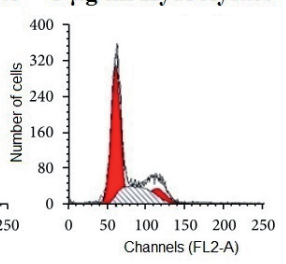

B

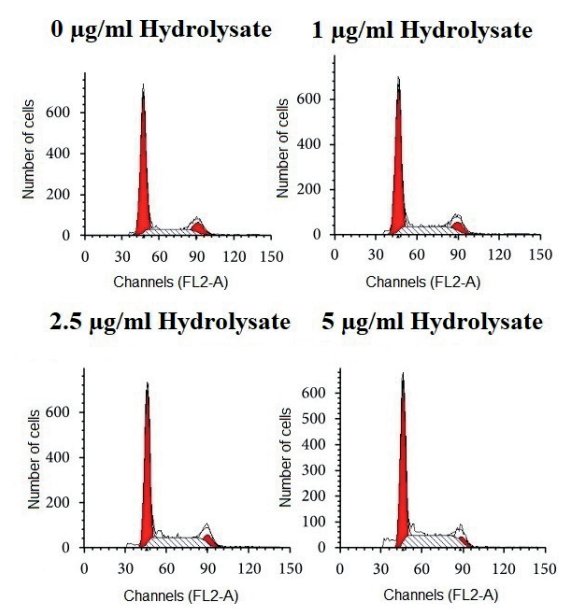

MCF-7

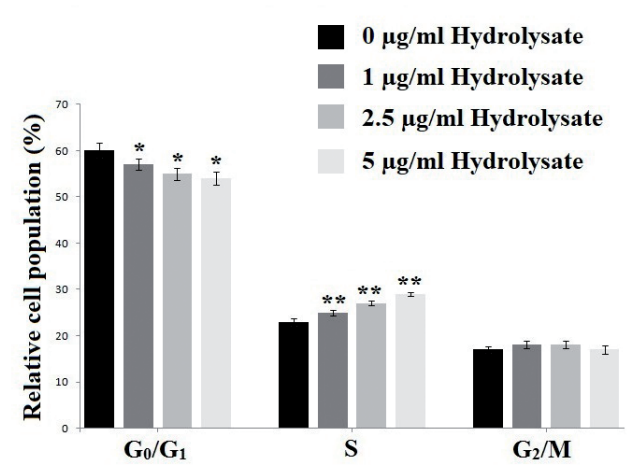

MDA-MB-231

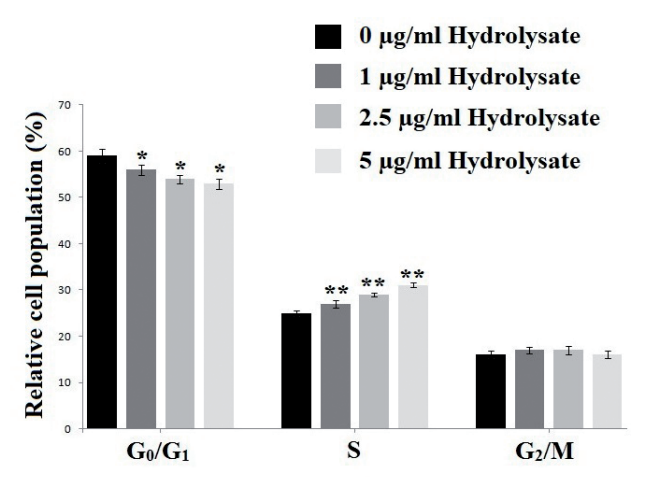

Figure 4. Effects of roe protein hydrolysate on the cell cycle. The cell cycle distributions in MCF-7 cells (A) and MDA-MB-231 cells (B) were determined by propidium iodide staining and flow cytometry analysis after being treated with different concentrations of roe protein hydrolysate $(0,1,2.5$, and $5 \mu \mathrm{g} / \mathrm{ml})$ for $48 \mathrm{~h}$. The ratios are expressed as the mean ratios $\pm \mathrm{SD}$ of three independent experiments. * statistically significantly lower than $0 \mu \mathrm{g} / \mathrm{ml}$ hydrolysate-treated group $(p<0.05)$; ** statistically significantly higher than $0 \mu \mathrm{g} / \mathrm{ml}$ hydrolysate-treated group $(p<0.05)$. cells were found to be $0.5 \%$ in the Control group, $0.1 \%$ at $2.5 \mu \mathrm{g} / \mathrm{ml}$, and $0.2 \%$ at $5 \mu \mathrm{g} / \mathrm{ml}$ roe protein hydrolysatetreated groups (Fig. 5B) $(p>0.05)$. The number of late apoptotic cells increased to $47.2 \%$ at $2.5 \mu \mathrm{g} / \mathrm{ml}$ and $50.2 \%$ at $5 \mu \mathrm{g} / \mathrm{ml}$ of protein hydrolysate for MCF-7 cells $(p<0.05)$ (Fig. $5 \mathrm{~A}$ ), and $38.1 \%$ at $2.5 \mu \mathrm{g} / \mathrm{ml}$ and $48.1 \%$ at $5 \mu \mathrm{g} / \mathrm{ml}$ of protein hydrolysate for MDA-MB-231 cells $(p<0.05)$ (Fig. 5B).

Upgrading in the level of ROS or/and reduction in the level of antioxidants can trigger mitochondrial-initiated events leading to apoptosis. Furthermore, production of ROS can disrupt the homeostasis in the enzyme system of ROS scavenging antioxidants. Generation of ROS was measured in the treated MCF-7 and MDA-MB-231 cells with different concentrations of roe protein hydrolysate. In our study, exposure to hydrolysate caused the significant production of intracellular ROS in dose-dependent manner in the treated MCF-7 and MDA-MB-231 cells $(p<$ 0.05) (Fig. 6).

Significantly increased expressions of caspase- 3 and caspase- 7 were detected in both cell lines in the presence of roe protein hydrolysate $(5 \mu \mathrm{g} / \mathrm{ml})$ at $48 \mathrm{~h}(p<0.05)$. Roe protein hydrolysate at the concentration of 2.5 and $5 \mu \mathrm{g} / \mathrm{ml}$ induced significant increases in relative caspase- 8 and caspase- 9 intensity in MCF-7 and MDA-MB-231 cells compared to the untreated cells $(p<0.05)$ (Fig. 7A). Significantly increased expression of $\mathrm{p} 53$ were observed after $48 \mathrm{~h}$ of incubation with roe protein hydrolysate in both cell lines $(p<0.05)$. However, the hydrolysate showed significant down-regulation on COX-2 levels in MCF-7 cells $(p<0.05)$ while no significant decreased levels of COX-2 in MDA-MB-231 were observed $(p>0.05)$ (Fig. 7B). TNF- $\alpha$ and Fas protein expressions increased significantly after hydrolysate treatment compared to control group in a dose-dependent manner in both cell lines 
$(p<0.05)$ (Fig. 7B). Significant increases in Bax expression and decreases in Bcl-2 levels were observed in hydrolysate treated MCF-7 and MDA-MB-231 cells after $48 \mathrm{~h}$ compared to the untreated cells $(p<0.05)$ (Fig. 7C). On the other hand, the hydrolysate lead to significant $(p<0.05)$ decreases in the expression of ErbB-2 in both cell lines (Fig. 7C).

\section{Discussion}

The protein hydrolysates of fishes have been reported to be a potential source for anticancer activity. It has been evidenced that some peptides isolated from fish tissues exhibit anticancer activity, inhibit the cell proliferation and also have cytotoxic effect against tumor cells (Shahidi and Zhong 2008; Hsu et al. 2009). In the present study, protein hydrolysate of A. tarichi roe showed dose-dependent anticancer activity on MCF-7 and MDA-MB-231 cells. Furthermore, protein hydrolysate had shown relatively higher antiproliferative activities on MCF-7 cells at each concentration than on MDA-MB-231 cells. The reason of this situation is probably because MDA-MB-231 is more resistant to anticancer treatment since it is derived from a cancerous site that was in metastatic status (Cedolini et al. 2014). Similarly Picot et al. (2006) recognised that protein hydrolysates of three cod, three plaice, three blue whiting and one salmon species acted
A

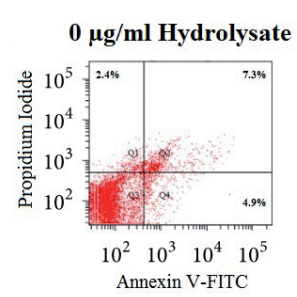

$2.5 \mu \mathrm{g} / \mathrm{ml}$ Hydrolysate

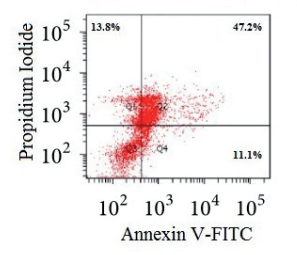

B
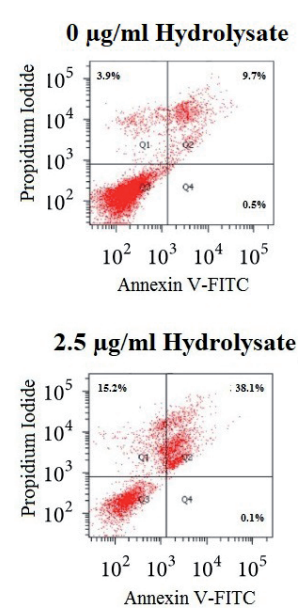
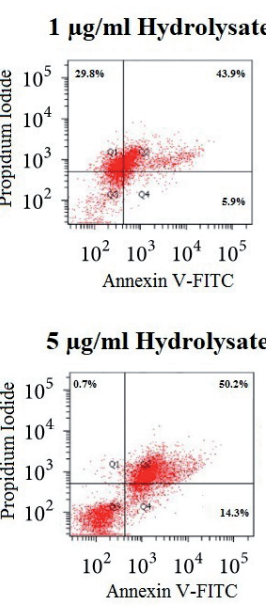

Q1: Necrosis

Q2: Late Apoptosis

Q3: Viable Cell
Q4: Early Apoptosis

\section{MCF-7}

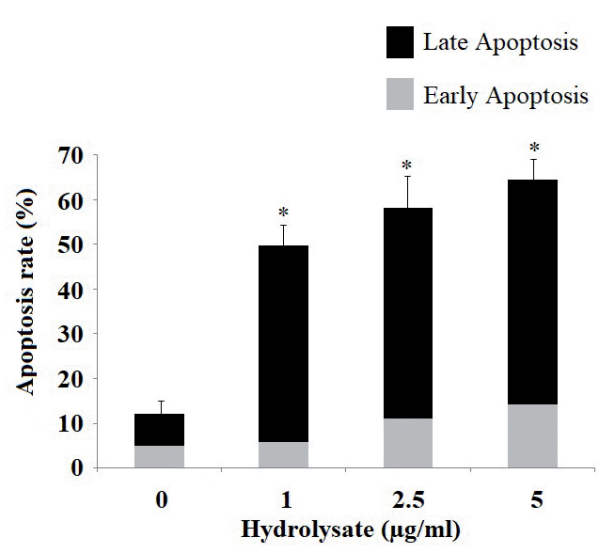

MDA-MB-231

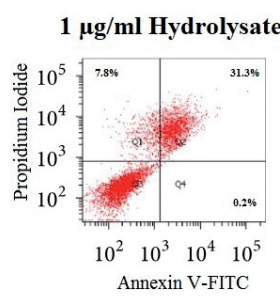

Q1: Necrosis

Q2: Late Apoptosis

Q3: Viable Cell

Q4: Early Apoptosis

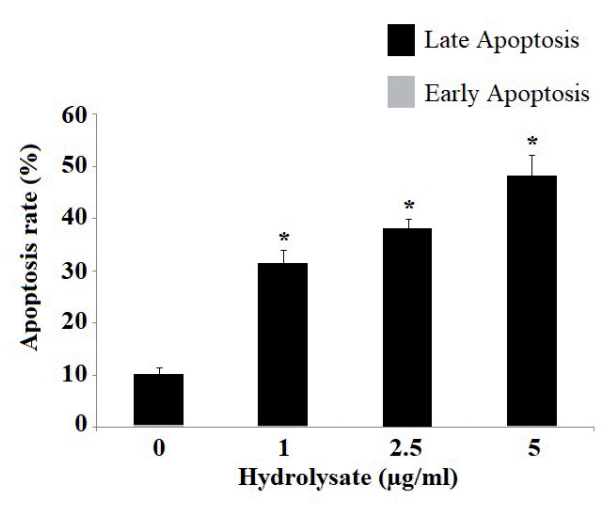

Figure 5. Flow-cytometry analysis of roe protein hydrolysate-induced apoptosis in MCF-7 cells (A) and MDA-MB-231 cells (B). The cells were treated with the indicated concentrations of hydrolysate for $48 \mathrm{~h}$, followed by labeling for phosphatidylserine externalization with FITC-annexin-V and cell membrane integrity with PI. Apoptotic staining profiles were analysed using flow cytometry. Independent experiments were performed in triplicate. Data are expressed as mean \pm SD. FITC, fluorescein isothiocyanate; PI, propidium iodide. ${ }^{*}$ statistically significantly higher than $0 \mu \mathrm{g} / \mathrm{ml}$ hydrolysate-treated group $(p<0.05)$. 


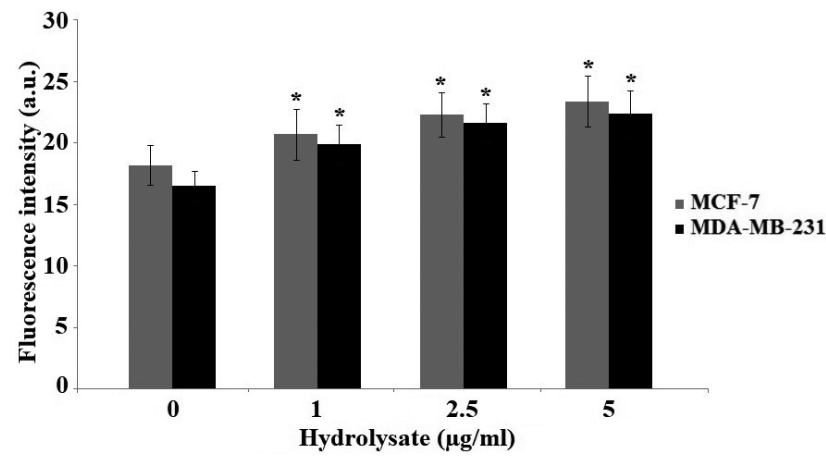

Figure 6. The effect of roe protein hydrolysate treatment on ROS generation in MCF-7 and MDA-MB-231 cells. Independent experiments were performed in triplicate. Data are expressed as mean \pm SD. ROS, reactive oxygen species. ${ }^{*}$ statistically significantly higher than $0 \mu \mathrm{g} / \mathrm{ml}$ hydrolysate-treated group $(p<0.05)$.

as significant inhibitors against MCF-7/6 and MDA-MB-231 human breast carcinoma cell lines. Alemán et al. (2011) also reported anticancer activity of esperase and alcalase hydrolysed squid gelatin hydrolysates on MCF-7 cells. In addition Hsu et al. (2011) also documented anticancer activity of papain and protease hydrolysates of tuna dark muscle on MCF-7 cells in dose-dependent manner.

The $\mathrm{IC}_{50}$ value of the present study was comparably lower than the reported value of Naqash and Nazeer (2012) for Nemipterus japonicus $(48.5 \mu \mathrm{g} / \mathrm{ml})$ and Exocoetus volitans $(21.6 \mu \mathrm{g} / \mathrm{ml})$ muscle protein hydrolysates in liver carcinoma cell line (Hep-G2). Further, Alemán et al. (2011) reported the $\mathrm{IC}_{50}$ values of esperase and alcalase squid gelatin hydrolysates on MCF-7 cells at $24 \mathrm{~h}$ as $0.15 \mathrm{mg} / \mathrm{ml}$ and $1.18 \mathrm{mg} / \mathrm{ml}$, respectively. In addition, Hsu et al. (2011) also recorded the $\mathrm{IC}_{50}$ values of papain and protease hydrolysates of tuna dark muscle on MCF-7 cells as $8.1 \mu \mathrm{M}$ and $8.8 \mu \mathrm{M}$, respectively.

DNA fragmentation is a typical indicator of apoptosis but not with the other mode of cell death like necrosis. The mechanism of action of several anticancer drugs is based on their capacity to induce apoptosis (Motomura et al. 2008). In the present study, DNA fragmentation assay was observed for displaying the apoptotic reaction. Lee et al. (2004) studied anticancer activity of peptide isolated from anchovy sauce, and their capabilities to induce apoptosis in U937 human lymphoma cell and revealed that hydrophobic peptide was found to have strong antiproliferative activity against U937 cell by inducing apoptosis.

The morphological changes of the cells treated with protein hydrolysate of $A$. tarichi roe were visualized. The results revealed that the untreated control MCF-7 and MDAMB-231 cells did not show any morphological changes. But the treated cells were shown irregular confluent aggregates with rounded and polygonal cell morphology and which was found to be more with increasing the concentrations of protein hydrolysate. Similarly, Wang et al. (2012) also reported morphological changes in the A549 cells treated with Syngnathusin, a novel peptide isolated from Syngnathus acus.

The majority of anti-cancer studies have reported perturbation of the $S / G_{2}$ phase transition with a decrease of cells in the $G_{0} / G_{1}$ phase of the cell cycle and an increase of cells in the $S$ phase (Lin et al. 2013). In the present study, the percentage proportion was increased in the $\mathrm{S}$ phase cells and reduced in the $G_{0} / G_{1}$ phase cells following roe protein hydrolysate treatment in a dose-dependent manner, indicating that the inhibitory effect of roe protein hydrolysate extract on MCF-7 and MDA-MB-231 cell proliferation is mediated by $S$ phase cell cycle arrest.

To our knowledge, the inhibition of cell proliferation is involved in apoptosis and block of cell cycle progression. It has been reported that sea squirt (Halocynthia roretzi) hydrolysate induced HT-29 colon cancer cells apoptosis via the increased expression of p53 and the modulation of Bcl-2/Bax protein expression (Oh et al. 2019). Hung et al. (2014) reported that protein hydrolysates from tuna cooking juice induced MCF-7 cells apoptosis by the detection of flow cytometry. Similar to these results, protein hydrolysate of $A$. tarichi roe induces the onset of apoptosis on MCF-7 and MDA-MB-231 cells in the current study.

ROS plays a key role in various biochemical processes like apoptosis and cell proliferation. However, high levels of ROS can also cause cellular damage, depending on the levels and duration of ROS stress (Pelicano et al. 2004). Hence, by exploiting these dose-dependent ROS generation, we can trigger cell death by using exogenous ROS-generating agents. In our study, protein hydrolysate of $A$. tarichi roe was found to increase the ROS generation on MCF-7 and MDA-MB-231 cells. Hence, protein hydrolysate of $A$. tarichi roe may be overlooked as a potential exogenous candidate generating ROS to induce apoptosis in breast cancer cells.

The activation of caspase- 3 and caspase- 7 were observed in both cell lines after treatment with protein hydrolysate which is consistent with the resulting morphological changes and the DNA fragmentation (Kumar 1999). Therefore, the results suggested that protein hydrolysate-induced MCF-7 and MDA-MB-231 cells death was involved in a mechanism of caspase-dependent apoptosis. On the other hand, protein hydrolysate treatment increased caspase- 8 and caspase- 9 expressions and induced apoptosis in MCF-7 and MDAMB-231 cells. These results suggest that protein hydrolysate triggers apoptosis via a combination of intrinsic and extrinsic pathways.

Studies have suggested that the up-regulation of the p53 protein is in accordance with growth inhibition of cancerous cells when exposed to various anti-cancer agents (Sun 2006; Comşa et al. 2015; Engeland 2018). In our study, the expression of p53 increased significantly in protein hydrolysatetreated MCF-7 and MDA-MB-231 cells and suggests that 


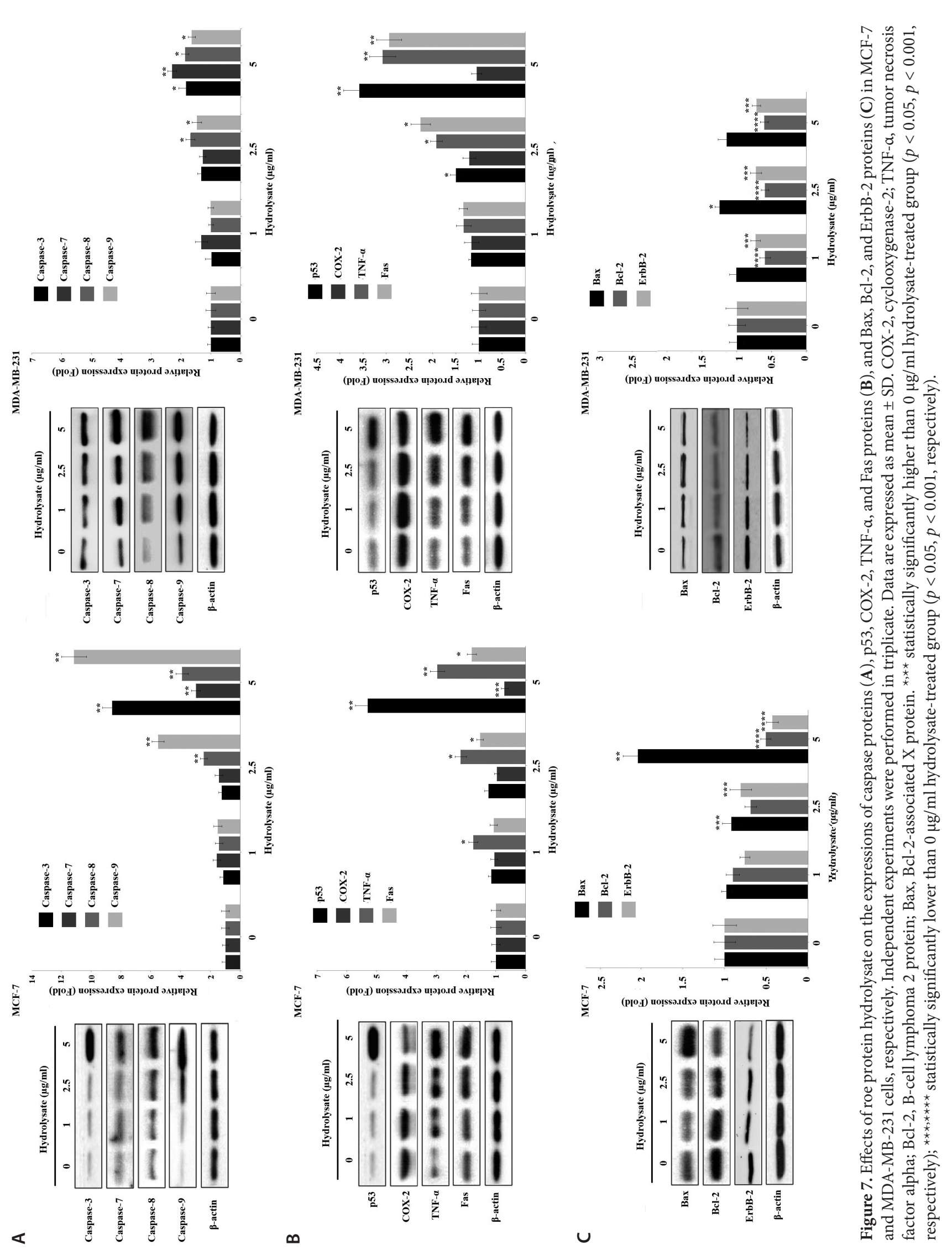


protein hydrolysate up-regulates the activated p53 which may either trigger the onset of DNA repair or induces the apoptosis via mitochondrial-dependent pathway by regulating the expressions of downstream molecules such as Bax, Bcl-2, and Fas. COX-2 over-expression may result in the suppression of proapoptotic proteins such as Bax and Bcl-xL during apoptosis (Sarkar et al. 2007; Thill et al. 2014; Regulski et al. 2016). In our research, the protein hydrolysate displayed a down-regulating effect on COX-2 expression in MCF-7 cells; while the COX-2 expression remained unchanged in a MDA-MB-231 cell line. These results suggested that protein hydrolysate suppress the expression of COX-2 which leads to the cell growth inhibition via decreasing of estrogen levels in an ER-positive MCF-7 cell line; however, protein hydrolysate has no effect on regulating COX-2 expression in an ER-negative MDA-MB-231 cell line. This result is agree with the previous study by Harris et al. (1999), who suggested that PGs may also stimulate proliferation indirectly via increased estrogen biosynthesis in breast tissue.

Studies have demonstrated that MCF-7 cells are sensitive to TNF- $\alpha$-induced apoptosis and that TNF- $\alpha$ is an effective inducer of apoptosis in MCF-7 cells (Watabe et al. 2004; Kuo et al. 2005; Modiano and Bellgrau 2016). In this study, protein hydrolysate treatment induced the increases in expressions of TNF- $\alpha$, Fas, and caspase- 8 in MCF-7 and MDA-MB-231 cells. These data suggest that the protein hydrolysate stimulated apoptosis by inducing death receptor-mediated pathway. Previous studies have demonstrated the importance of $\mathrm{Bax} / \mathrm{Bcl}-2$ ratio in regulating the mitochondria-mediated apoptotic pathway in human breast cancer models (Shim et al. 2007). Our data showed that protein hydrolysate treatment increased the expression of Bax while down-regulating the Bcl-2 expressions, which happened along with the increased expressions of caspase- 9 and apoptosis in MCF-7 and MDA-MB-231 cells. Therefore, these results clearly indicate that the mechanism of protein hydrolysate-induced apoptosis by mitochondrial-mediated pathway involves the mitochondrial membrane potential change via controlling the $\mathrm{Bax} / \mathrm{Bcl}-2$ ratio. Previous studies suggest that down-regulation of ErbB-2 could efficiently suppress the breast tumor cell growth (Chen et al. 2008, 2014). In this study, protein hydrolysate treatment showed a down-regulating effect on ErbB-2 expression in MCF-7 and MDA-MB-231 cells, and thus suggest that protein hydrolysate may enhance the apoptotic signal by suppressing the expression of ErbB-2.

In conclusion, potential therapeutic value of protein hydrolysate of $A$. tarichi roe and further research in animal tumor models is necessary to confirm its anti-cancer activity in vitro. The impact of this study provides information on cell specific pathways affected by this protein hydrolysate and could open avenues for the use of the protein hydrolysate of A. tarichi roe as a nutraceutical diet/drug for breast cancer prevention. In addition, this research provides insight on the molecular mechanism of action of the protein hydrolysate of A. tarichi roe against human breast cancer cells and results on its potential drug-like property. The production of this protein hydrolysate is less expensive than general cancer drug and could be a promising alterative strategy to current expensive anti-cancer therapies.

Acknowledgements. The author sincerely thanks the laboratory technicians and assistants in Jagiellonian University, Medical Collage, Department of Food Chemistry and Nutrition.

Author contributions. MB generated the idea, did the literature review, carried out the laboratory works, did the statistical analysis, and wrote the manuscript. OY, ÖT, and MK analyzed and interpreted the lab test. FÖY and AÖH defined the species of fish and prepared the hydrolysate.

Conflict of interest. The authors do not have any conflict of interest to declare.

Funding. This research was financially supported in part by the Office of Scientific Research Projects of Yuzuncu Yil University under Grant number (TAP-2018-6956).

\section{References}

Akter R, Hossain MZ, Kleve MG, Gealt MA (2012): Wortmannin induces MCF-7 breast cancer cell death via the apoptotic pathway, involving chromatin condensation, generation of reactive oxygen species, and membrane blebbing. Breast Cancer (Dove Med Press) 4, 103-113 https://doi.org/10.2147/BCTT.S31712

Alemán A, Pérez-Santin E, Bordenave-Juchereau S, Arnaudin I, Gómez-Guillén MC, Montero P (2011): Squid gelatin hydrolysates with antihypertensive, anticancer and antioxidant activity. Food Res. Int. 44, 1044-1051 https://doi.org/10.1016/j.foodres.2011.03.010

Allen RT, Hunter WJ 3rd, Agrawal DK (1997): Morphological and biochemical characterization and analysis of apoptosis. J. Pharmacol. Toxicol. Methods 37, 215-228 https://doi.org/10.1016/S1056-8719(97)00033-6

Bligh EG, Dyer WJ (1959): A rapid method of total lipid extraction and purification. Can. J. Biochem. Physiol. 37, 911-917 https://doi.org/10.1139/y59-099

Cassidy J, Misset JL (2002): Oxaliplatin-related side effects: characteristics and management. Semin. Oncol. 29, 11-20 https://doi.org/10.1053/sonc.2002.35524

Cedolini C, Bertozzi S, Londero AP, Bernardi S, Seriau L, Concina S, Cattin F, Risaliti A (2014): Type of breast cancer diagnosis, screening, and survival. Clin. Breast Cancer 14, 235-240 https://doi.org/10.1016/j.clbc.2014.02.004

Chen FL, Xia W, Spector NL (2008): Acquired resistance to small molecule ErbB2 tyrosine kinase inhibitors. Clin. Cancer Res. 14, 6730-6734 https://doi.org/10.1158/1078-0432.CCR-08-0581 
Chen M, He M, Song Y, Chen L, Xiao P, Wan X, Dai F, Shen P (2014): The cytoprotective role of gemcitabine-induced autophagy associated with apoptosis inhibition in triple-negative MDA-MB-231 breast cancer cells. Int. J. Mol. Med. 34, 276-282 https://doi.org/10.3892/ijmm.2014.1772

Comşa Ş, Cîmpean AM, Raica M (2015): The story of MCF-7 breast cancer cell line: 40 years of experience in research. Anticancer Res. 35, 3147-3154

Engeland K (2018): Cell cycle arrest through indirect transcriptional repression by p53: I have a DREAM. Cell Death Differ. 25, 114-132 https://doi.org/10.1038/cdd.2017.172

Espinosa E, Zamora P, Feliu J, González-Barón M (2003): Classification of anticancer drugs--a new system based on therapeutic targets. Cancer Treat. Rev. 29, 515-523 https://doi.org/10.1016/S0305-7372(03)00116-6

Harris RE, Robertson FM, Abou-Issa HM, Farrar WB, Brueggemeier R (1999): Genetic induction and upregulation of cyclooxygenase (COX) and aromatase (CYP19): an extension of the dietary fat hypothesis of breast cancer. Med. Hypotheses 52, 291-292 https://doi.org/10.1054/mehy.1998.0009

Hsu KC, Li-Chan EC, Jao CL (2011): Antiproliferative activity of peptides prepared from enzymatic hydrolysates of tuna dark muscle on human breast cancer cell line MCF-7. Food Chem. 126, 617-622 https://doi.org/10.1016/j.foodchem.2010.11.066

Hsu KC, Lu GH, Jao CL (2009): Antioxidative properties of peptides prepared from tuna cooking juice hydrolysates with orientase (Bacillus subtilis). Food Res. Int. 42, 647-652 https://doi.org/10.1016/j.foodres.2009.02.014

Hung CC, Yang YH, Kuo PF, Hsu KC (2014): Protein hydrolysates from tuna cooking juice inhibit cell growth and induce apoptosis of human breast cancer cell line MCF-7. J. Funct. Foods 11, 563-570 https://doi.org/10.1016/j.jff.2014.08.015

Kumar S (1999): Regulation of caspase activation in apoptosis: implications in pathogenesis and treatment of disease. Clin. Exp. Pharmacol. Physiol. 26, 295-303 https://doi.org/10.1046/j.1440-1681.1999.03031.x

Kuo PL, Hsu YL, Chang CH, Lin CC (2005): The mechanism of ellipticine-induced apoptosis and cell cycle arrest in human breast MCF-7 cancer cells. Cancer Lett. 223, 293-301 https://doi.org/10.1016/j.canlet.2004.09.046

Lee YG, Lee KW, Kim JY, Kim KH, Lee HJ (2004): Induction of apoptosis in a human lymphoma cell line by hydrophobic peptide fraction separated from anchovy sauce. Biofactors 21, 63-67 https://doi.org/10.1002/biof.552210112

Lin W, Zheng L, Zhuang Q, Shen A, Liu L, Chen Y, Sferra TJ, Peng J (2013): Spica Prunellae extract inhibits the proliferation of human colon carcinoma cells via the regulation of the cell cycle. Oncol. Lett. 6, 1123-1127 https://doi.org/10.3892/ol.2013.1512

Lind DS, Hochwald SN, Malaty J, Rekkas S, Hebig P, Mishra G, Moldawer LL, Copeland EM 3rd, Mackay S (2001): Nuclear factor-kappa B is upregulated in colorectal cancer. Surgery 130, 363-369 https://doi.org/10.1067/msy.2001.116672
Mendis AS, Thabrew I, Samarakoon SR, Tennekoon KH (2015): Modulation of expression of heat shock proteins and apoptosis by Flueggea leucopyrus (Willd) decoction in three breast cancer phenotypes. BMC Complement. Altern. Med. 15, 404 https://doi.org/10.1186/s12906-015-0927-6

Modiano JF, Bellgrau D (2016): Fas ligand based immunotherapy: A potent and effective neoadjuvant with checkpoint inhibitor properties, or a systemically toxic promoter of tumor growth? Discov. Med. 21, 109-116

Motomura M, Kwon KM, Suh SJ, Lee YC, Kim YK, Lee IS, Kim MS, Kwon DY, Suzuki I, Kim CH (2008): Propolis induces cell cycle arrest and apoptosis in human leukemic U937 cells through Bcl-2/Bax regulation. Environ. Toxicol. Pharmacol. 26, 61-67 https://doi.org/10.1016/j.etap.2008.01.008

Naqash SY, Nazeer RA (2012): Optimization of enzymatic hydrolysis conditions for the production of antioxidant peptides from muscles of Nemipterus japonicus and Exocoetus volitans using response surface methodology. Amino Acids 43, 337-345 https://doi.org/10.1007/s00726-011-1084-y

Oğuz AR (2018): Development of osmoregulatory tissues in the Lake van fish (Alburnus tarichi) during larval development. Fish Physiol. Biochem. 44, 227-233 https://doi.org/10.1007/s10695-017-0427-3

Oh Y, Shim KB, Ahn CB, Kim SS, Je JY (2019): Sea Squirt (Halocynthia roretzi) hydrolysates induce apoptosis in human colon cancer HT-29 cells through activation of reactive oxygen species. Nutr. Cancer 71, 118-127 https://doi.org/10.1080/01635581.2018.1540717

Pelicano H, Carney D, Huang P (2004): ROS stress in cancer cells and therapeutic implications. Drug Resist. Updat. 7, 97-110 https://doi.org/10.1016/j.drup.2004.01.004

Picot L, Bordenave S, Didelot S, Fruitier-Arnaudin I, Sannier F, Thorkelsson G, Berge JP, Guerard F, Chabeaud A, Piot JM (2006): Antiproliferative activity of fish protein hydrolysates on human breast cancer cell lines. Proc. Biochem. 41, 12171222 https://doi.org/10.1016/j.procbio.2005.11.024

Pilane MC, Bagla VP, Mokgotho MP, Mbazima V, Matsebatlela TM, Ncube I, Mampuru L (2015): Free radical scavenging activity: Antiproliferative and proteomics analyses of the differential expression of apoptotic proteins in MCF-7 cells treated with acetone leaf extract of Diospyros lycioides (Ebenaceae). Evid. Based Complement. Alternat. Med. 2015, 534808 https://doi.org/10.1155/2015/534808

Regulski M, Regulska K, Prukała W, Piotrowska H, Stanisz B, Murias M (2016): COX-2 inhibitors: a novel strategy in the management of breast cancer. Drug Discov. Today 21, 598-615 https://doi.org/10.1016/j.drudis.2015.12.003

Sarkar FH, Adsule S, Li Y, Padhye S (2007): Back to the future: COX-2 inhibitors for chemoprevention and cancer therapy. Mini Rev. Med. Chem. 7, 599-608 https://doi.org/10.2174/138955707780859431

Shahidi F, Zhong Y (2008): Bioactive peptides. J. AOAC Int. 91, 914-931 https://doi.org/10.1093/jaoac/91.4.914

Shim HY, Park JH, Paik HD, Nah SY, Kim DS, Han YS (2007): Acacetin-induced apoptosis of human breast cancer MCF-7 cells involves caspase cascade, mitochondria-mediated death 
signaling and SAPK/JNK1/2-c-Jun activation. Mol. Cells 24, 95-104

Sun Y (2006): p53 and its downstream proteins as molecular targets of cancer. Mol. Carcinog. 45, 409-415 https://doi.org/10.1002/mc.20231

Thill M, Terjung A, Friedrich M (2014): Breast cancer--new aspects of tumor biology: are calcitriol and cyclooxygenase-2 possible targets for breast cancer? Eur. J. Gynaecol. Oncol. 35, 341-358

Wagner C, Vargas AP, Roos DH, Morel AF, Farina M, Nogueira CW, Aschner M, Rocha JB (2010): Comparative study of quercetin and its two glycoside derivatives quercitrin and rutin against methylmercury (MeHg)-induced ROS production in rat brain slices. Arch. Toxicol. 84, 89-97 https://doi.org/10.1007/s00204-009-0482-3

Wang M, Nie Y, Peng Y, He F, Yang J, Wu C, Li X (2012): Purification, characterization and antitumor activities of a new protein from Syngnathus acus, an officinal marine fish. Mar. Drugs 10, 35-50 https://doi.org/10.3390/md10010035

Watabe M, Hishikawa K, Takayanagi A, Shimizu N, Nakaki T (2004): Caffeic acid phenethyl ester induces apoptosis by inhibition of NFkappaB and activation of Fas in human breast cancer MCF-7 cells. J. Biol. Chem. 279, 6017-6026 https://doi.org/10.1074/jbc.M306040200

Zhen H, Zhang Y, Fang Z, Huang Z, You C, Shi P (2014): Toona sinensis and Moschus Decoction induced cell cycle arrest in human cervical carcinoma HeLa cells. Evid. Based Complement. Alternat. Med. 2014, 121276 https://doi.org/10.1155/2014/121276

Zhu N, Wang Z (1997): An assay for DNA fragmentation in apoptosis without phenol/chloroform extraction and ethanol precipitation. Anal. Biochem. 246, 155-158 https://doi.org/10.1006/abio.1997.2018

Received: September 24, 2019

Final version accepted: June 21, 2020 